\title{
Earthworm services: an agroecological perspective
}

\author{
Ortiz-Ceballos, Ángel Isauro $^{1 *}$; Lara-González, Rogelio ${ }^{1}$; Guevas-Díaz, María del Carmen² \\ Martínez-Velázquez, Katia Jassiel ${ }^{1}$ \\ 1 Instituto de Biotecnología y Ecología Aplicada (INBIOTECA), Universidad Veracruzana, Av. de las Culturas \\ Veracruzanas 101, Col. E. Zapata, 91090, Xalapa, Veracruz, México. \\ 2 Facultad de Ciencias Químicas, Campus Coatzacoalcos, Universidad Veracruzana, Av. Universidad Km \\ 7.5, Col. Santa Isabel, 96538, Coatzacoalcos, Veracruz, México. \\ * Correspondence: angortiz@uv.mx
}

Gitation: Ortiz-Ceballos, Á. I., LaraGonzález, R., Cuevas-Díaz, M. del C., \& Martínez-Velázquez, K. J. (2021). Earthworm services: an agroecological perspective. Agro Productividad. https:// doi.org/ 10.32854/agrop.vl4i12.2029

Editor in Chief: Dr. Jorge Cadena Iñiguez

Received: May 7, 2021.

Accepted: December 13, 2021. Published on-line: December 30, 2021.

Agro Productividad, 14(12). December. 2021. pp: 99-109.

\section{This work is licensed under a}

Creative Commons Attribution-NonCommercial 4.0 International license.

\begin{abstract}
Objective: To review and discuss the invisible and silent role of the activity of earthworms, which are considered "agroecosystem engineers".

Design/methodology/approach: A database search of scientific articles published in Mexico and worldwide was performed.

Results: The literature reviewed shows that earthworms constitute the most abundant biomass in the vast majority of tropical agroecosystems. In addition, earthworms have long been shown to improve a) soil structure; b) interaction with symbiotic microorganisms; c) nutrient mineralization and availability; d) pollutant removal; e) regulation of foliar herbivory; and f) crop yields.

Limitations on study/implications: Most studies have been conducted in laboratories and greenhouses. Findings/conclusions: Earthworms increase soil quality and agricultural productivity. Their protection, promotion, and management are suggested in order to manage, preserve, and restore soil health, as well as to ensure a sustainable crop production.
\end{abstract}

Keywords: Regenerative Agriculture, Environmental Services, Traditional Agriculture, Bioindicators, Bioremediation.

\section{INTRODUCTION}

The presence of earthworms in crop fields is as old as agriculture. Plants have likely evolved along with earthworms (Blakemore, 2009; Ortiz-Ceballos et al., 2019); in other words, they are an essential biological component of sustainable agroecosystems. However, conventional agriculture is frequently criticized for its negative impact on soil quality and human health. A better management of earthworms living in crop fields can solve this problem (Bertrand et al., 2015). In fact, agricultural management studies and programs aimed at increasing soil fertility, degrading organic pollutants, and increasing crop yields, among other things, do not usually take earthworms into consideration.

Before the development of artificial fertilizers and agricultural mechanization, the essential role that earthworms play in agroecosystems had already been suggested by Aristotle, Darwin, and other scientists (Van Groenigen et al., 2019). However, earthworms 
are commonly known and referred to as Eisenia fetida (used in worm composting or vermicomposting), when in fact the soils of various terrestrial ecosystems and agroecosystems are home to a vast diversity of earthworms (Villalobos-Maldonado et al., 2017). Scientists see earthworms as "ecosystem engineers" as a result of the profound agroecological impact they have on the physicochemical and biological properties of soil (Blakemore, 2009). Most of the studies focused on earthworms have used species adapted to crops, most of which are considered invasive; for instance, in the case of the tropical regions of Mexico and the world, it is very common to find the Pontoscolex corethrurus earthworm in conventional agroecosystems — which use fertilizers, herbicides, pesticides, and tillage - and in industrial and urban areas — polluted with heavy metals, crude oil, and others (Taheri et al., 2018; Ortiz-Gamino et al., 2020; Ortiz-Ceballos et al., 2019). In Mexico, the native species Balanteodrilus pearsei has a remarkable presence in traditional agroecosystems (OrtizCeballos et al., 2004; Huerta et al., 2005; Fragoso and Rojas, 2014; Fragoso et al., 2015). In this review, written from an agroecological viewpoint, we analyze the largely ignored earthworm services and their potential to encourage agricultural sustainability in Mexico.

\section{Species diversity in Mexico and the world}

Earthworms are segmented worms with terrestrial habits. Their lifecycle is synchronized with the soil's temperature and moisture and their length $(1 \mathrm{~cm}-1 \mathrm{~m})$ and width $(2 \mathrm{~mm}-3 \mathrm{~cm})$ may vary. They belong to the phylum Annelida, class Clitellata, and order Crassiclitellata (Fragoso and Rojas, 2014). Currently, 5,900 to 6,000 species live in the majority of moist soils in the world; however, it is unlikely to find them in arid and cold areas (Fragoso and Rojas, 2014). There are more earthworm species in Mexico —102 species, equally distributed among native and introduced species - than in several European countries, while in Latin America only Brazil, Colombia, and Ecuador have more species (Fragoso and Rojas, 2014). The most studied tropical regions have been eastern and southeastern Mexico. Veracruz, for instance, has the largest number of known species, followed by Chiapas, Tamaulipas, and Tabasco (Fragoso and Rojas, 2014). The species diversity in tropical agroecosystems is larger than in temperate ones: it varies between four and six species and is rarely larger than ten (Fragoso and Rojas, 2014).

\section{Ecological categories and/or functional groups}

Earthworms are grouped in ecological categories or functional groups based on their color, size and body shape, location in the soil, burrowing capacity, and food preference (Bertrand et al., 2015; Van Groenigen et al., 2019). Unpigmented endogeic earthworms build horizontal tunnels in the topsoil and consume soil, organic matter, and soil organisms. Meanwhile, epigeic earthworms live in the soil surface and feed on decaying vegetable material. Finally, the anecic earthworm species are pigmented, they build permanent vertical tunnels or burrows in the mineral layers of the soil, feed on vegetable material, and ingest soil (Bertrand et al., 2015; Van Groenigen et al., 2019).

In Mexico, 92\% of earthworms are endogeic (soil feeders). The ten most common species in agricultural soils are: a) introduced species: Pontoscolex corethrurus, Octalasion tyrtaeum, Amynthas gracilis, Dichogaster bolaui, and Aporrectodea trapezoides; and b) native species: 
Phoenicodrilus taste, Balanteodrilus pearsei, Diplotrema murchiei, Protozapotecia aquilonalis, and Lavellodrilus parvus (Fragoso and Rojas, 2014). By contrast, the widely known epigeic Eisenia fetida ("California red worm") does not dwell in Mexican agricultural soils.

\section{Population size}

Earthworm abundance and diversity are determined by crop type, agricultural practices, and the organic residues added to the soil (Manono, 2016). The change in land use also alters the diversity, abundance, and distribution of earthworms. In addition, their survival depends on moisture, temperature, texture, $\mathrm{pH}$, and on symbiont soil microorganisms (Bertrand et al., 2015). Earthworms are therefore assessed for their abundance and biomass. In the tropical regions of Mexico, earthworms have been found in the following type of soils: Arenosols, Fluvisols, Vertisols, Acrisols, Luvisols, Phaeozems, Leptosols, and Andosols. A greater abundance (ind $/ \mathrm{m}^{2}$ ) of earthworms in these soils has been registered in grasslands (76-704), followed by lands used for coffee (482), cocoa (170), citrus (145), eucalyptus (115), maize (51-222), home gardens (20-110), rain forests (31-170), fallow (298), and others (Ortiz-Ceballos et al., 2005; Huerta et al., 2005; Uribe et al., 2012; García-Pérez et al., 2017).

\section{Soil structure}

Earthworms choose mineral and organic particles according to the ecological categories to which they belong (Bertrand et al., 2015; Sánchez-Hernández, 2019). When endogeic and anecic earthworms consume soil for food and to burrow (to build galleries and nests), they mix it in their intestine and produce aggregates (excreta) that contain fragments of the organic matter, organisms, and minerals that were found in the ingested soil. Consequently, earthworm activity contributes to soil formation through the improvement of porosity and aggregation by providing more (Bertrand et al., 2015): a) water flow and retention; b) gas exchange; c) creation of habitats for organisms (microfauna and mesofauna); d) availability of easily absorbed nutrients; e) root growth and carbohydrate release; and f) nutrient absorption for plants.

Earthworm soil ingestion rates are highly variable: $1-30 \mathrm{~g}$ of dry soil/g fresh weight/day (Bertrand et al., 2015). Ingestion has a negative relation to age and size: juveniles consume more soil than adults, while smaller ones consume more than larger ones (Bertrand et al., 2015). Therefore, earthworms are capable of regenerating the structure of compacted soils.

\section{Symbiont microorganisms}

The most common impact of earthworm activity can be seen on soil microorganisms and it takes place through two compartments: gastrointestinal tract (internal) and movement and feeding (external), associated with the improvement of soil structure (Bertrand $e t$ al., 2015, Medina-Sauza et al., 2019; Li et al., 2021). In the first case, some studies have demonstrated the presence of symbiont microorganisms that dwell in the gastrointestinal tract (bioreactor). In addition, earthworm eggs and nephridia (excretory organs) host symbiotic microbiomes (Aira et al., 2018; Li et al., 2021). In the second case, the earthworm mechanical activity modifies habitats and microbial communities that dwell in the soil. 
The latter obtain a double benefit from earthworms' movement: they either adhere to their bodies or they are ingested by earthworms, survive, and are subsequently scattered (Aira et al., 2018; Medina-Sauza et al., 2019; Li et al., 2021). Tunnel walls, excreta, and nests are microenvironments with a high microbial and enzyme activity (Van Groenigen et al., 2019). Therefore, the presence of earthworms in the soil promotes a greater abundance of symbiont microorganisms of the phyla Proteobacteria, Actinobacteria, Firmicutes, Acidobacteria, Planctomycetes, Bacteriodetes, Nitrospirae, and Chloroflexi, that are essential for the survival of earthworms; these microorganisms are capable of degrading organic matter, removing pollutants, releasing easily-absorbed nutrients, and promoting plant growth (Ortiz-Ceballos et al., 2019; Medina-Sauza et al., 2019; Li et al., 2021).

\section{Soil detoxification}

Bioremediation has become a usual means to reduce the concentration and toxicity of soil pollutants (Hickman and Reid, 2008; Datta et al., 2016; Villalobos-Maldonado et al., 2017; Sánchez-Hernández, 2019). During the last decade, different studies have pointed out that the impact of the physical (improvement of airing and aggregation), chemical (alteration of $\mathrm{pH}$ and $\mathrm{OM}$ ), and biological activity of endogeic and anecic earthworms on the degradation of crude oil, heavy metals, pesticides, and herbicides, among other things has increased (Hickman and Reid, 2008; Datta et al., 2016; Sánchez-Hernández, 2019). Environmental works that seek to remedy polluted soils do not take earthworms into consideration (Hickman and Reid, 2008; Datta et al., 2016; Sánchez-Hernández, 2019), despite the fact that P. corethrurus, Glossodrilus sp., Dichogaster saliens, Protozapotecia australis, and Onychochaeta windlei earthworms dwell in soils that have been polluted by the oil industry of Veracruz and Tabasco (Zavala et al., 2013; Hernández-Castellanos $e t$ al., 2013a; García-Segura et al., 2018). In addition, toxicological trials have shown that $P$. corethrurus avoids and/or repels concentrations above 10,000 $\mathrm{mg}$ of total crude petroleum hydrocarbons $(\mathrm{TPH}) / \mathrm{kg}$ of dry soil and the median lethal concentration $\left(\mathrm{CL}_{50}\right)$ of 3,067.3 mg TPH/kg (Guevas-Díaz et al., 2017). In Mexico, bioremediation studies showed that the presence of $P$. corethrurus and organic amendments reach a 35.6\% reduction of benzo(a) pyrene (Hernández-Castellanos et al., 2013b) and 86.0\% of TPH (Rodríguez-Campos et al., 2019). Furthermore, earthworms have been found to increase the availability and mobility of essential ( $\mathrm{Zn}, \mathrm{Cu}, \mathrm{Mn}, \mathrm{Fe})$ and non-essential $(\mathrm{Cd}, \mathrm{Pb}, \mathrm{Hg}$ ) metals in both polluted and non-polluted soils (Taheri et al., 2018). P. corethrurus, for instance, significantly reduced the amount of $\mathrm{Pb}$; additionally, it promotes the $\mathrm{Pb}$ phytoextraction capacity of Lantana camara (Taheri et al., 2018). Finally, this species tolerates Carbaril (insecticide) concentrations, but Carbendazim (fungicide) and Carbofuran (insecticide) have a lethal effect on it. The response of $P$. corethrurus to herbicides (glyphosate) is variable: the use of glyphosate in coffee crops reduces earthworm abundance and biomass (García-Pérez et al., 2014), but it does not affect reproduction in the laboratory (García-Pérez et al., 2016). Hickman and Reid (2008) and Datta et al. (2016) have therefore suggested that endogeic earthworms can be used as indicators of agricultural, industrial, and urban soil health, as well as to restore degraded soils. 


\section{Nutrient availability}

Since they consume and degrade a vast diversity of organic materials, earthworms directly affect soil fertility, increasing total $\mathrm{OM}(40-48 \%)$, total $\mathrm{P}$, and total $\mathrm{N}$ concentrations (Van Groenigen et al., 2019). This is the result of biochemical transformation processes that occur in the digestive tract of earthworms and that involve: a) production of endogenous cellulases (Ean-Eg, EF-EG2, and GHF9); b) association with intestinal microbiota (Protobacteria, Firmicutes, Actinobacteria, Chloroflexi, and Bacteroidetes); c) gene expression (transcriptome) that adjusts their digestive system (salivation, gastric acid, and pancreatic secretion); d) improvement of the digestive efficiency based on caecum type; and e) association with nephridial bacteria (Pedobacter) (Ortiz-Ceballos et al., 2019). It has thus been demonstrated that total element concentration substantially increases in earthworm excreta: $241 \%$ and $84 \%$ for mineral $\mathrm{N}$ and available P, respectively (Van Groenigen et al., 2019); moreover, there is a significant increase in $\mathrm{pH}$ (0.5 units), in cation exchange capacity (40\%), and in base saturation (27\%). In addition, earthworms accumulate, store, and recycle carbon and nitrogen in their biomass. They have a low carbon assimilation efficiency (2-27\%; maximum: 70\%), depending on the species, density, organic matter quality, and temperature. Nonetheless, the amount of nitrogen circulating through their biomass is higher than carbon - the estimated values fluctuate between 60 and $100 \mathrm{~kg} / \mathrm{ha} /$ year-, which suggests an important flow of this nutrient in agroecosystems. Therefore, an appropriate management of organic residues or management practices (cover crops, intercropping, crop rotation, and no-till farming or minimum tillage), can maintain abundant earthworm populations, in order to synchronize the release of easily absorbed nutrients that will then be available for plants when they need it. This suggests the need to design and improve agroecosystems that maintain soil fertility to achieve a sustainable crop production (Bertrand et al., 2015) - for instance cocoa, coffee, maize, and other agroecosystems in which the farmers of southeastern Mexico are involved (Brown et al., 2004; Ortiz-Ceballos et al., 2005; Huerta et al., 2005; Juárez-Ramón and Fragoso, 2014; Fragoso et al., 2015; García-Pérez et al., 2017). Finally, earthworms are soil improving agents that cannot be studied separately from agroecosystems (Van Groenigen et al., 2019) (Figure 1).

\section{Earthworm-plant-insect interaction}

Almost nothing is known about the effects of soil organisms on a vast range of natural enemies: predators and parasitoids (Wurst, 2013; Heinen et al., 2018; Thakur et al., 2021). Although conceptual frameworks are well developed and some interactions are well studied (e.g., mycorrhizae), gaps still exist regarding the biodiversity knowledge about other taxa that are closely associated with plant roots, such as earthworms (Shelef et al., 2019; Li et al., 2021). Soil organisms play a significant role in the configuration of plant-insect interactions in the field, with general patterns for some taxa, such as earthworms (Heinen et al., 2018). Results show that plants use earthworm excreted nutrients and assimilate them into their roots, leaf tissue, and phloem sap, which is sucked by aphids (Shelef et al., 2019; Thakur et al., 2021). This, in turn, shows that earthworms in the soil and aphids on the plants are functionally interconnected. Earthworm presence increased the production of the plants' 


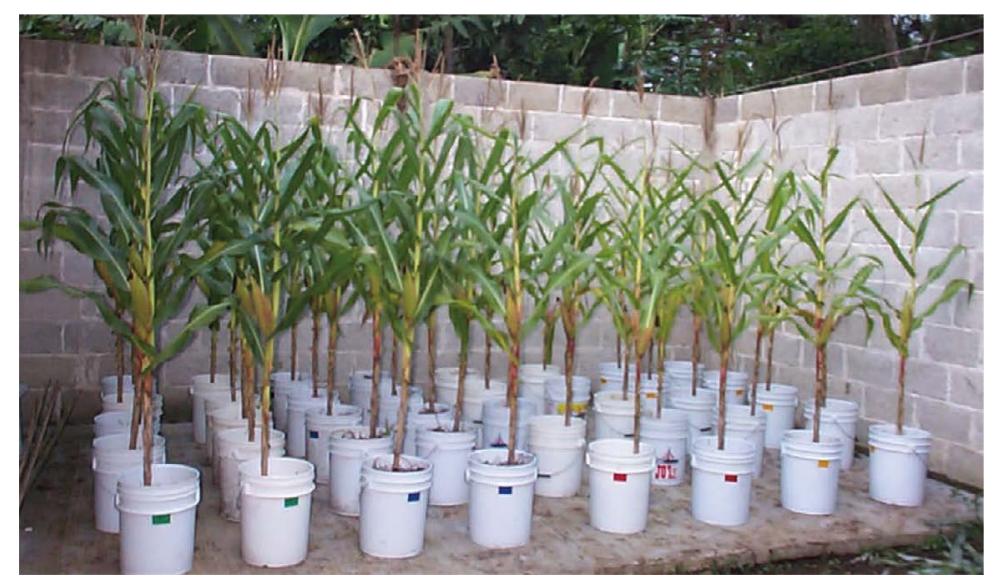

Figure 1. Effects of the native tropical earthworm Balanteodrilus pearsei on the growth of the corn crop. Trays with labels: Green=Soil+Legume Foliage+Earthworm; Blue=Soil+Legume Foliage; Red=Soil+Earthworm; Yellow $=$ Soil + Earthworm.

chemical defenses against cell feeders (trips) by $31 \%$ and their resistance against trips by $81 \%$. Both results were associated to earthworm abundance and diversity (Xiao et al., 2017). Results suggest the need of a better integration of soil fauna into plant-herbivore interaction studies, both in applied and basic research. This opens up opportunities to explore the manipulation of soil organisms in agriculture or ecosystem restoration. Some groups can be promising agents for the improvement and protection of crop yield and can affect plant diversity on the soil at a community level, which allows the use of soil organisms to guide vegetation development (Wurst, 2013; Heinen et al., 2018) (Figure 2,3,4,5).

\section{Plant growth and productivity}

Epigeic, endogeic, and anecic earthworm activity has an important beneficial effect on plant growth and productivity because it: a) provides a greater amount of nutrients; b) improves soil structure; c) stimulates microbial symbionts of plants; d) controls pests and illnesses; and e) produces plant growth regulating substances (Ortiz-Ceballos et al., 2007; Van Groenigen et al., 2014). During their assessment of the three main basic crops (corn, wheat, and rice) and pastures in 58 studies conducted in almost every continent-
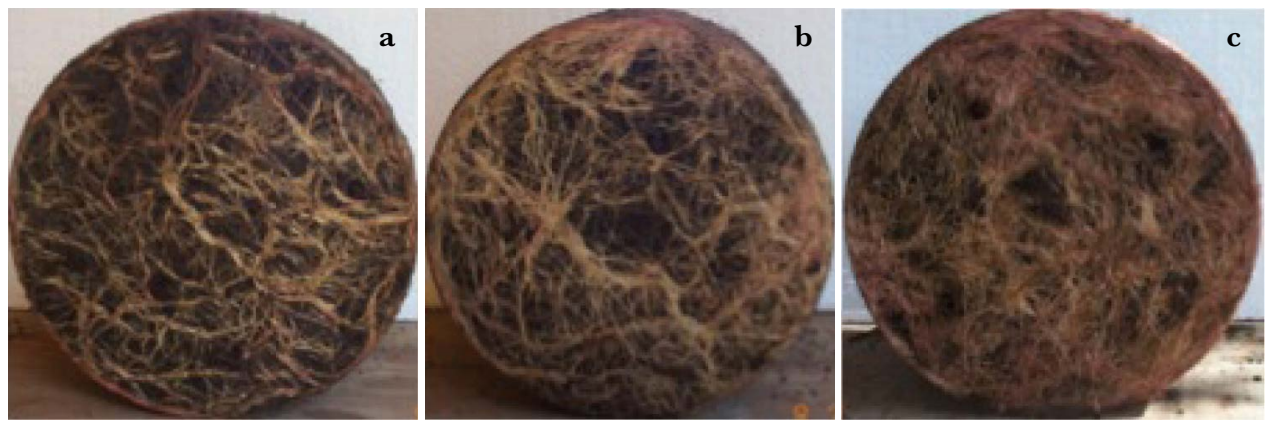

Figure 2. Effect of the native tropical earthworm Balanteodrilus pearsei on the growth of the roots of the corn crop: a) Soil+Earthworm; b) Soil+Legume Foliage; c) Soil+Earthworm+Legume Foliage. 


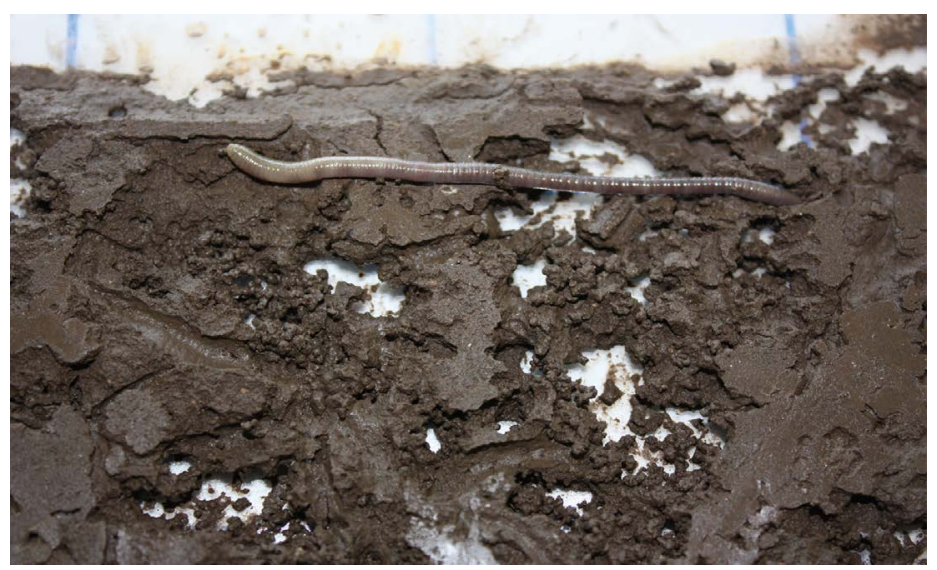

Figure 3. Construction of galleries and production of excreta of the native tropical earthworm Balanteodrilus pearsei.

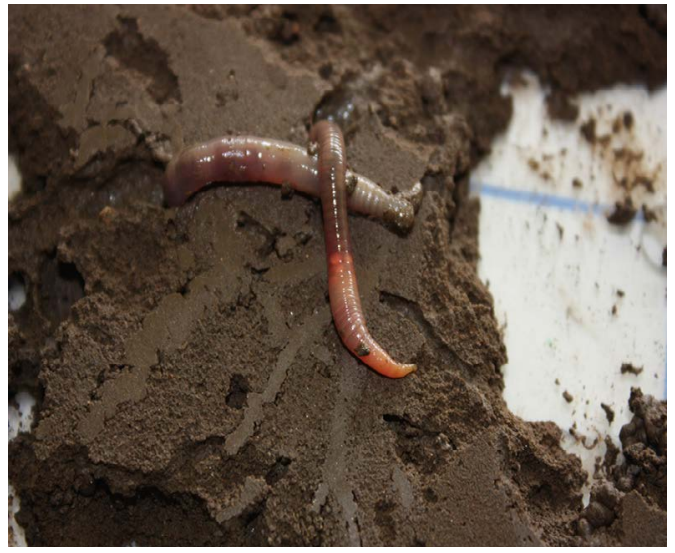

Figure 4. Exotic tropical earthworm Pontoscolex corethrurus.

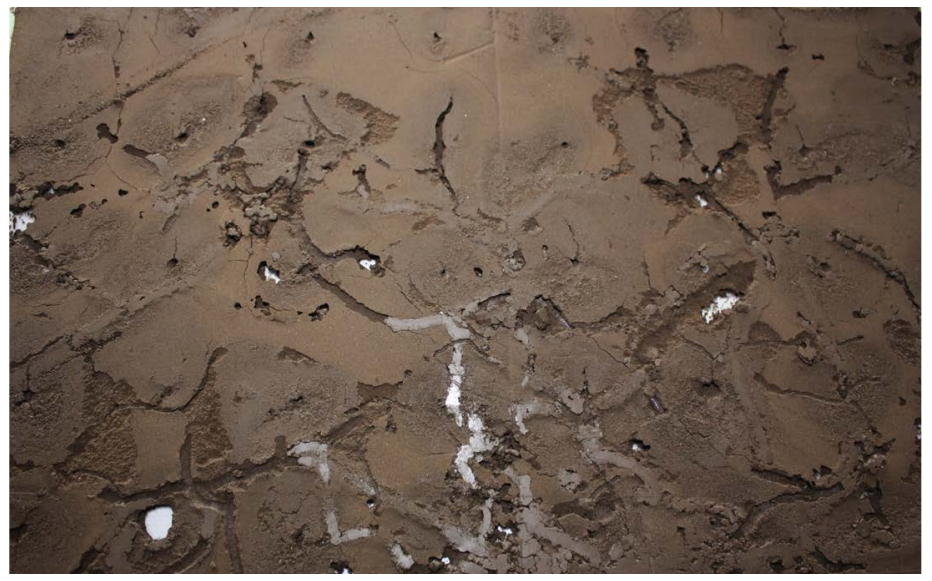

Figure 5. Construction of galleries and production of excreta of the exotic tropical earthworm Pontoscolex corethrurus. 


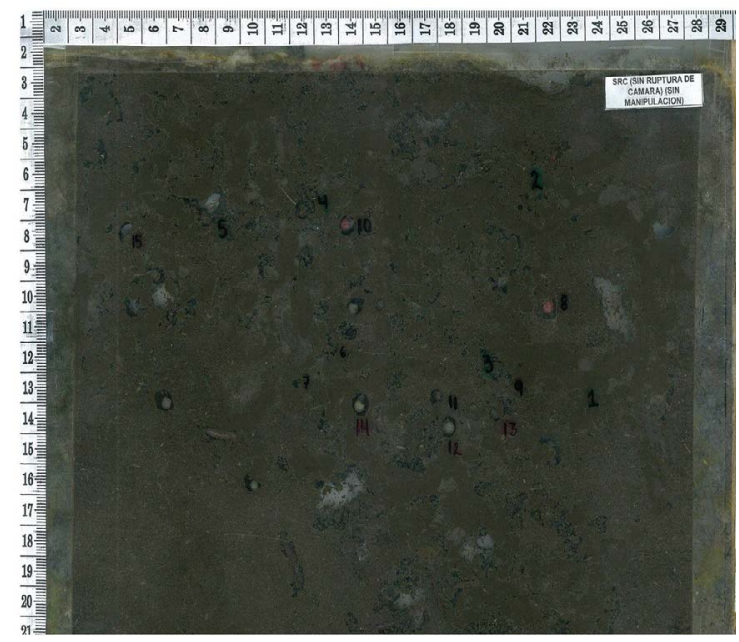

Figure 6. Cocoon and excreta production of the endogenous earthworm Pontoscolex corethrurus.

save in Antarctica-, Van Groenigen et al. (2014) determined that earthworms significantly increased crop yields (25\%), aerial biomass (23\%), roots (20\%), and total biomass (21\%). The most important effects on grain production are achieved with a $>30-40 \mathrm{~g}$ fresh weight $/ \mathrm{m}^{2}$ biomass (Van Groenigen et al., 2014). Nevertheless, ecological, and agricultural studies have been conducted for the handling of only 11 out of 102 species in Mexico. Among them P. corethrurus, Polypheretima elongate, and B. pearse $i$ stand out as a result of their potential in situ use in agroecology and/or in regenerative agriculture (Fragoso and Rojas, 2014). For instance, the presence of $B$. pearse $i$ and $P$. corethrurus earthworms with the velvetbean legume (Mucuna pruriens var. utilis) significantly increased the growth and production of corn, vanilla, and Roma tomato crops (Ortiz-Ceballos et al., 2007); moreover, used in nurseries, they boosted the growth of Abies religiosa (Sánchez-Velásquez et al., 2019) and Quercus insignis forest seedlings (Avendaño-Yáñez et al., 2017). However, domestication has turned hundreds of traditional plant species to intensive farming (Porter and Sachs, 2020). Farming practices and intense selective breeding used to increase yields can involve a hidden cost: the interruption of interactions between plants and earthworms (Porter and Sachs, 2020). It is therefore suggested that, in order to improve a sustainable agricultural production, agroecological research must develop methods to optimize relations between cultivated plants and soil organisms (Porter and Sachs, 2020).

\section{CONGLUSIONS}

Over the last 150 years, the relevance of earthworms and their evolution with domesticated plants have been attested (Braga et al., 2016). Therefore, it is very likely that earthworm services contribute to increase agricultural sustainability improving human health (Bertrand et al., 2016). This suggests the need of long-term field studies about the impact of earthworms on crop production. In addition, agricultural grants and funding are required to design and promote agroecosystems that take into account the intrinsic value of earthworms and the effect of crop practices on earthworm diversity, abundance, and activity (Bertrand et al., 2015; Scown et al., 2020). 


\section{REFERENGES}

Aira, M., Pérez-Losada, M., \& Domínguez, J. (2018). Diversity, structure and sources of bacterial communities in earthworm cocoons. Scientific Reports 8: 6632 https://doi.org/10.1038/s41598-018-25081-9

Avendaño-Yáñez M.L., Ortiz-Ceballos A.I., Sánchez-Velásquez L.R., Pineda-López M.R., Meave, J.A. (2014). Synergic Effect of Mucuna pruriens var. utilis (Fabaceae) and Pontoscolex corethrurus (Oligochaeta, Glossoscolecidae) on the Growth of Quercus insignis (Fagaceae) Seedlings, a Native Species of the Mexican Cloud Forest Seedlings, a Native Species of the Mexican Cloud Forest. Open Journal of Forestry 4(1): 1-7. https://doi.org/10.4236/ojf.2014.41001

Bertrand, M., Barot, S., Blouin, M., Whalen, J., de Oliveira, T., \& Roger-Estrade, J. (2015). Earthworm services for cropping systems. A review. Agronomy for Sustainable Development 35: 553-567. https://doi. org/10.1007/s13593-014-0269-7

Blakemore, R. J. (2009). Cosmopolitan Earthworms-A Global and Historical Perspective. In Annelids in Modern Biology (pp. 257-283). https://doi.org/10.1002/9780470455203.ch14

Braga, L. P. P., Yoshiura, C. A., Borges, C. D., Horn, M. A., Brown, G. G., Drake, H. L., \& Tsai, S. M. (2016). Disentangling the influence of earthworms in sugarcane rhizosphere. Scientific Reports 6: 1-13. https:/ doi.org/10.1038/srep38923

Brown, G. G., Moreno, A. G., Barois, I., Fragoso, G., Rojas, P., Hernández, B., \& Patrón, J. G. (2004). Soil macrofauna in SE Mexican pastures and the effect of conversion from native to introduced pastures. Agriculture, Ecosystems and Environment 103(2): 313-327. https://doi.org/10.1016/j.agee.2003.12.006

Datta, S., Singh, J., Singh, S., \& Singh, J. (2016). Earthworms, pesticides and sustainable agriculture: a review. Environmental Science and Pollution Research 23(9): 8227-8243. https://doi.org/10.1007/s11356-0166375-0

Cuevas-Díaz, M.C., Vázquez-Luna, D., Martínez-Hernández, S., Guzmán-López, O., \& Ortíz-Ceballos, A. I. (2017). Sensitivity of the Endogeic Tropical Earthworm Pontoscolex corethrurus to the Presence of Heavy Crude Oil. Bulletin of Environmental Contamination and Toxicology 99(2): 154-160. https://doi. org/10.1007/s00128-017-2126-2

Fragoso, C., \& Rojas, P. (2014). Biodiversity of earthworms (Annelida: Oligochaeta: Crassiclitellata) in Mexico. Revista Mexicana de Biodiversidad 85: S197-S207 https://doi.org/10.7550/rmb.33581

Fragoso, C., Leyequién E., Carcía-robles, M., Montero-Muñoz J., Rojas, P. (2015). Dominance of native earthworms in secondary tropical forests derived from slash-and-burn Mayan agricultural practices (Yucatán, Mexico). Applied Soil Ecology 104: 116-124. https://doi.org/10-1016/j.apsoil.2015.12.005

García-Pérez, J.A., Alarcón-Gutiérrez, E., Perroni, Y., Barois, I. (2014). Earthworm communities and soil properties in shaded coffee plantations with and without application of glyphosate. Applied Soil Ecology 83: 230-237. http://dx.doi.org/10.1016/j. apsoil.2013.09.006.

García-Pérez, J.A., Alarcón, E., Hernández, Y., Hernández, C., (2016). Impact of litter contaminated with glyphosate-based herbicide on the performance of Pontoscolex corethrurus, soil phosphatase activities and soil pH. Applied Soil Ecology 104: 31-41. http://dx.doi.org/10.1016/j.apsoil.2016.03.007.

García-Pérez, J.A., Barois, I., Bueno, J., Fragoso, C., Kram S., Meza E., Morón M.A., Negrete S., Rojas, P., de los Santos M., Sormani, C. (2017). Concervacion y manejo de la biodiversidad del suelo en la sierra de Santa Marta, Los Tuxtlas Veracruz México: La macrofauna del suelo en la sierra de Santa Marta. En: Reynoso, V.H., Coates, R.I. y Vázquez Cruz M.L. (eds.) Avances y perspectivas en la invetstigación de los bosques tropicales y sus alrrededores. La región de los Tuxtlas. Institituo de biología, UNAM. México. 195-238 pp. file://Users/Usuario/Downloads/2017_Garcaetal._Cap.13.LaMacrofaunadelsue loenlasierradeSantaMarta\%20(1).pdf

García-Segura, D., Castillo-Murrieta, I. M., Martínez-Rabelo, F., Gomez-Anaya, A., Rodríguez-Campos, J., Hernández-Castellanos, B., Contreras-Ramos, S. M., \& Barois, I. (2018). Macrofauna and mesofauna from soil contaminated by oil extraction. Geoderma 332: 180-189. https://doi.org/10.1016/J. GEODERMA.2017.06.013

Heinen, R., Biere, A., Harvey, J. A., \& Bezemer, T. M. (2018). Effects of Soil Organisms on Aboveground Plant-Insect Interactions in the Field: Patterns, Mechanisms and the Role of Methodology. Frontiers in Ecology and Evolution 6: 106. https://doi.org/10.3389/fevo.2018.00106

Hernández-Castellanos, B., Ortíz-Ceballos, A.I., Martínez-Hernández, S., Noa-Carrazana, J. C., LunaGuido, M., Dendooven, L., \& Contreras-Ramos, S. M. (2013). Removal of benzo (a) pyrene from soil using an endogeic earthworm Pontoscolex corethrurus (Müller, 1857). Applied Soil Ecology 70: 62-69. https://doi.org/10.1016/j.apsoil.2013.04.009

Hernández-Castellanos B, J. Zavala-Cruz, S. Martínez-Hernández, L. Dendooven, S.M. Contreras-Ramos, J.C. Noa-Carrazana, C. Fragoso, A. I. Ortiz-Ceballos. (2013). Earthworm Populations in an Aged 
Hydrocarbon Contaminated Soil. Research Journal of Environmental Sciences 7(1): 27-37. https://doi. org/10.3923/rjes.2013.27.37

Hickman, Z. A., \& Reid, B. J. (2008). Earthworm assisted bioremediation of organic contaminants. Environment International 34(7): 1072-1081. https://doi.org/10.1016/j.envint.2008.02.013

Huerta, E., Rodríguez-Olán, J., Evia-Castillo, I., Montejo-Meneses, E., de la Cruz-Mondragón, M., \& GarcíaHernández, R. (2005). La diversidad de lombrices de tierra (annelida, oligochaeta) en el estado de Tabasco, México. Universidad y Ciencia 21(42): 75-85.

Juárez-Ramón, D., \& Fragoso, C. (2014). Comunidades de lombrices de tierra en sistemas agroforestales intercalados, en dos regiones del centro de México. Acta Zoológica Mexicana (N.S.) 30(3): 637-654. https://doi.org/10.21829/azm.2014.30383

Li, H., Yang, X. R., Wang, J., Zhou, G. W., Zhang, Y. Sen, Lassen, S. B., .. Su, J. Q. (2021). Earthworm gut: An overlooked niche for anaerobic ammonium oxidation in agricultural soil. Science of the Total Environment 752: 141874. https://doi.org/10.1016/j.scitotenv.2020.141874

Manono, B. (2016). Agro-ecological Role of Earthworms (Oligochaetes) in Sustainable Agriculture and Nutrient Use Efficiency: A Review. Journal of Agriculture and Ecology Research International 8(1): 1-18. https://doi.org/10.9734/jaeri/2016/24517

Medina-Sauza, R. M., Álvarez-Jiménez, M., Delhal, A., Reverchon, F., Blouin, M., Guerrero-Analco, J. A., ... Barois, I. (2019). Earthworms building up soil microbiota, a review. Frontiers in Environmental Science 7: 1-20. https://doi.org/10.3389/fenvs.2019.00081

Ortiz-Ceballos, A. I., \& Fragoso, C. (2004). Earthworm populations under tropical maize cultivation: The effect of mulching with velvetbean. Biology and Fertility of Soils 39(6): 438-445. https://doi.org/10.1007/ s00374-004-0732-8

Ortiz-Ceballos, A. I., Fragoso, C., \& Brown, G. G. (2007). Synergistic effect of a tropical earthworm Balanteodrilus pearsei and velvetbean Mucuna pruriens var. utilis on maize growth and crop production. Applied Soil Ecology 35(2): 356-362. https://doi.org/10.1016/j.apsoil.2006.07.009

Ortiz-Ceballos, A. I., Aguirre-Rivera, J. R., Salgado-Garcia, S., \& Ortiz-Ceballos, G. (2015). Maize-velvet bean rotation in summer and winter milpas: A greener technology. Agronomy Journal 107(1): 330-336. https://doi.org/10.2134/agronj14.0276

Ortíz-Ceballos, A. I., Ortiz-Gamino, D., Andrade-Torres, A., Pérez-Rodríguez, P., \& López-Ortega, M. (2019). Pontoscolex corethrurus: A homeless invasive tropical earthworm? PLoS ONE 14(9): 1-13. https:// doi.org/10.1371/journal.pone.0222337

Ortíz-Gamino, D., Gregorio, J., Gunha, L., Martínez-Romero, E., Fragoso, C., \& Ortíz-Ceballos, Á. I. (2020). Population genetics and diversity structure of an invasive earthworm in tropical and temperate pastures from Veracruz, Mexico. ZooKeys 941: 49-69. https://doi.org/10.3897/zookeys.941.49319

Porter, S. S., \& Sachs, J. L. (2020). Agriculture and the Disruption of Plant-Microbial Symbiosis. Trends in Ecology and Evolution 35: 426-439. https://doi.org/10.1016/j.tree.2020.01.006

Rodríguez-Campos, J., Perales-García, A., Hernández-Carballo, J., Martínez-Rabelo, F., HernándezCastellanos, B., Barois, I., \& Contreras-Ramos, S. M. (2019). Bioremediation of soil contaminated by hydrocarbons with the combination of three technologies: bioaugmentation, phytoremediation, and vermiremediation. Journal of Soils and Sediments 19: 1981-1994. https://doi.org/10.1007/s11368-0182213-y

Sánchez-Hernández, J. C. (2019). Bioremediation of Pesticide-Contaminated Soils by using Earthworms. In Bioremediation of Agricultural Soils. https://doi.org/10.1201/9781315205137-9

Sánchez-Velásquez, L. R., Vásquez-Morales, S. G., Lara-González, R., Ortiz-Ceballos, Á. I., del Rosario Pineda-López, M., \& Hernández-Vargas, G. (2019). Does the earthworm favor the survival and growth of Abies religiosa (Kunth) Schltdl. \& Cham. Seedlings in a nursery? Revista Chapingo, Serie Ciencias Forestales y Del Ambiente 26(1): 113-121. https://doi.org/10.5154/r.rchscfa.2019.04.039

Scown, M. W., Brady, M. V., \& Nicholas, K. A. (2020). Billions in Misspent EU Agricultural Subsidies Could Support the Sustainable Development Goals. One Earth 3(2): 237-250. https://doi.org/10.1016/j. oneear.2020.07.011

Shelef, O., Hahn, P. G., Pineda, A., Tejesvi, M. V, \& Martinez-medina, A. (2020). Below-Ground Interactions in Ecological Processes. https://doi.org/10.3389/978-2-88963-258-9

Taheri, S., Pelosi, C., \& Dupont, L. (2018). Harmful or useful? A case study of the exotic peregrine earthworm morphospecies Pontoscolex corethrurus. Soil Biology and Biochemistry 116: 277-289. https://doi. org/10.1016/j.soilbio.2017.10.030

Thakur, M. P., Künne, T., Unsicker, S. B., Biere, A., Ferlian, O., Pruschitzki, U., ... Eisenhauer, N. (2021). Invasive earthworms reduce chemical defense and increase herbivory and pathogen infection in native trees. Journal of Ecology 109(2): 763-775. https://doi.org/10.1111/1365-2745.13504 
Uribe, S., Huerta, E., Geissen, V., Mendoza, M., Godoy, R., \& Jarquín, A. (2012). Pontoscolex corethrurus (Annelida: Oligochaeta) indicador de la calidad del suelo en sitios de Eucalyptus grandis (Myrtacea) con manejo tumba y quema. Revista de Biologia Tropical 60(4): 1543-1552. https://doi.org/10.15517/rbt. v60i4.2072

Van Groenigen, J. W., Lubbers, I. M., Vos, H. M. J., Brown, G. G., De Deyn, G. B., \& Van Groenigen, K. J. (2014). Earthworms increase plant production: a meta-analysis. Scientific Reports 4: 6365. https://doi. org/10.1038/srep06365

Van Groenigen, J. W., Van Groenigen, K. J., Koopmans, G. F., Stokkermans, L., Vos, H. M. J., \& Lubbers, I. M. (2019). How fertile are earthworm casts? A meta-analysis. Geoderma, 338: 525-535. https://doi. org/10.1016/j.geoderma.2018.11.001

Villalobos-Maldonado, J.J., Meza-gordillo, R., Enciso-Sáenz, S., Castaño-González, J.H., Rosales-Quintero, A., Lagunas-Rivera S., Gutiérrez-Micelli, F.A., Ruíz-Valdiviezo, V.M., Rincón-Rosales, R. (2017) Identificación molecular de bacterias en Eisenia foetida Savigny cultivadas, con potencial de remoción de contaminates orgánicos persistentes. Agroproductividad 10(5): 51-56

Wurst, S. (2013). Plant-mediated links between detritivores and aboveground herbivores. Frontiers in Plant Science 4: 1-5. https://doi.org/10.3389/fpls.2013.00380

Xiao, Z., Wang, X., Koricheva, J., Kergunteuil, A., Le Bayon, R. C., Liu, M., ... Rasmann, S. (2018). Earthworms affect plant growth and resistance against herbivores: A meta-analysis. Functional Ecology 32(1): 150-160. https://doi.org/10.1111/1365-2435.12969

Zavala-Cruz, J., Fragoso, C., Martinez-Hernández, S., Ortiz-Ceballos, A. I., Dendooven, L., HernandezCastellanos, B., Contreras-Ramos, S. M., \& Noa-Carrazana, J. G. (2013). Earthworm Populations in an Aged Hydrocarbon Contaminated Soil. Research Journal of Environmental Sciences 7: 27-37. https:// doi.org/10.3923/rjes.2013.27.37 